\title{
EUHTE3E
}

Original Scientific Paper

2017, бр. 11, стр. 1 -38.

UDK 371.311 .5

doi:10.5937/sinteze6-14011

\section{PEDAGOGICAL COMMUNICATION - ACHIEVEMENT AND FREQUENCY IN GENERAL CLASS TEACHING}

\author{
Danijela S. Panićl, Dragana D. Lazic ${ }^{\prime *}$, Ljiljana Lj. Mitrović ${ }^{2}$
}

Abstract: This paper deals with pedagogical communications, that is, the frequency and achievement of communication in general class teaching. The aim of this research is definition of frequency and achievement of pedagogical communication, regarding the communication direction (pupil-teacher, teacherpupil and pupil-pupil). Also, the aim of this research is to define the frequency and successfulness during teaching of subjects group (common - educational and skills) and to define the communication relation regarding to the type, that is, group which teaching subject belongs to. The nature of problem and set aim of research determined that this research has an empirical character. From the set aim and objective of this research, the following research tasks are derived: to establish the incidence and successfulness of pedagogical communication towards teaching subjects in general class teaching on relations teacher-pupil, pupilteacher, pupil-pupil, over 300 lessons; to establish whether there is statistically significant difference in communication achievement and underachievement towards teaching subjects on relations, in general class teaching; to establish whether there is statistically significant difference in the communication incidence and achievement between common educational group of teaching subjects and skills.

The research was conducted by method of observing, noting and specially designed instrument for this kind of data and research was used. The results shows that the communication is the most incident and most achieved on relation teacher - pupil, as well as that achievement and underachievement of communications depends on the type of teaching subject. Since the pedagogical communication is very important part in pedagogical and educational work in our

\footnotetext{
${ }^{1}$ simeunovic.danijela@gmail.com, 1*draganaldj@gmail.com, Primary school „Knez Ivo od Semberije“, Bijeljina, Republic of Srpska, Bosnia and Herzegovina

2 mitroviclj@spinter.net, Primary school „Vuk Karadžić“, Zabrđe, Republic of Srpska, Bosnia and Herzegovina
} 
schools, this paper offers useful information for further studies, improvement of communication in teaching.

Key words: elementary school; achievement; teaching subject; class teaching; pedagogical communication

\section{INTRODUCTION}

Pedagogical communication largely represents the expression of essential understanding of teaching, its organization, applied didactical teaching systems, set aims and objectives, leading principles and used teaching methods and forms of work. The efficiency of pedagogical and educational process in teaching largely depends on established communication, interaction patterns among direct participants of that process. The consequence is creation of specific psychological, socioemotional, communicational climate, which can be more or less suitable for successful work. Communication in teaching enables related activity of teachers and pupils, pupils and pupils, teaching and learning. In its base, there is always some content, information that is mediated, on one side, and that is received and adapted, on the other side, where teacher and pupil constantly change roles.

Contemporary teaching represents the form of interconnected activity and cooperation of teachers and pupils. This cooperation is accomplished as their mutual interaction and communication. Thus, it is necessary for teacher to know how the communication in teaching runs and functions, how much do the teachers and pupils mutually cooperate, which types of verbal communications are accomplished between them and what is their structure. Pedagogical and educational work in contemporary school puts the communication and relation between pupils and teachers on the pivotal position. Communication reflects the conception of education where a pupil is object or subject, or both at the same time, and a teacher has multiple roles, from the function of aristocratic leader to router, collaborator, counsellor, etc.

One of the ways for modernization, improvement and raising efficiency of teaching is exactly the clarification of pedagogical communication importance and its theoretical and empirical study. In this way, it will be accomplished new practical knowledge and conclusions. Considering the current importance of the theme and its great significance in teaching, in this work we will deal with the probe of current condition of communicational part of teaching in elementary schools, of the accomplishment of communication on the relations of its accomplishment. 
By the examination, the incidence and accomplishment of pedagogical communication, on the relations teacher-pupil, pupil-teacher and pupil-pupil during the teaching of Serbian language, Maths, Science and Social Studies as the group of common educational school subjects and during the teaching of Art, Music, Physical Education as the group of skills, seeks to be determined. Also, the aim of this research is to determine the incidence and the efficiency of communication during the teaching of subject group (common educational ones and skills), as well as the relation between the efficiency, realization and non-realization and failure between them.

By accomplishing the tasks and confirmation or refutation of the hypothesis of this research, the results which will give a clear image of current incidence and efficiency of teaching communication are expected. It will set an obligation, to all participants of pedagogical and educational work, teachers and pupils, to permanently improve and develop teaching communication for the most comprehensive achievement of aims and outcomes of teaching plans which are regulated for all school subjects.

\section{COMMUNICATION}

Nowadays, the term communication is more frequently used. Overall early child's sociality testifies that there is a strong child's motivation for communication (Ivić, 1978: 171). The interaction with the environment, that is, different behaviour systems, like ,perception of human character and speech voices, the ability of establishing socioemotional connections and phenomenon of attachment to certain person, early non-verbal communication in two directions between a mother and a child, emerge at the earliest child's period (Graorac, 1995:121). The term communication comes from Latin word comunicare which means to make something general (Pedagoški leksikon, 1996). In this definition, it is acknowledged that communication is a social act and that it is bidirectional. If we understand the term communication in wider sense, then, the communication contents can be also material goods, energy and even social relations. The process of exchanging ideas, thoughts and feelings between two persons, which starts with certain conscious or unconscious intention and leads to interaction, understanding, bonding and influence, as well as knowledge increase of its participants, makes the term of pedagogical communication (Simeunović, 2009: 296).

Pedagogical communication means also training for communication, that is, the development of ability of one side, that is, the 
pupil's, to communicate with the other side or with the source of information. The main objective is to help the pupil to develop the abilities for successful and independent communication with other people and with the communication media. Suzić (2005), under the term pedagogical communication, means transfer, disclosure exposure, acceptance, that is, message exchange as well as establishing the relations, understanding, means and ways of behaviour between the participants in pedagogical and educational work and in learning process. Pedagogical communication is an important part of pedagogical work and a condition for achieving high quality school. Communication in school need to be clear, loud and understandable to all participants of communication, it is also a reflection of pupil's feeling and it directly impacts on his motivation, formation of positive relation towards work, development of consciousness about learning need and, finally, awareness of selfcriticism. Studying literature of teaching and communication in teaching, different classifications are encountered. According to Simeunovic, pedagogical communication can be classified on the basis of three criteria, the number of participants, considering the way of communication and means of communication (Simeunović, 2005: 297)

Considering the number of participants, communication divides into intrapersonal (inner speech), interpersonal (communication between two persons) group (communication conducted in smaller groups to 30 participants) and public (addressing to larger number of people, mostly omnidirectional). Vilotijević (2000) states that in educational and pedagogical work we discern the following communication types: personal and impersonal; verbal and non-verbal; omnidirectional and bidirectional; direct and indirect; and authorative and democratic communication. Brajša (1994) considers that talk with the teacher activates and develops the pupil's brain, thus, pupil's personality also develops. Teacher needs to know to listen to pupil, thus, the conversation between them need to be bidirectional.

Teaching (class and subject), as continuous pedagogical and educational work and communicational process consists of collection of factors, without which it would not exist. For a long time it was considered that teaching factors are pupil, teacher, teaching contents, which are interrelated, that is, they are in, so called, „didactical triangle“. In professional and scientific literature, there are different classifications of teaching factors, therefore, of communication factors. The most accepted division is on direct and indirect factors (Musić, 2010:46). Indirect communication factors are: pupil, teacher, teaching content and 
communication means and aids in teaching, and direct factors include teacher's traits, position of teacher and pupil in teaching process, atmosphere in class and micro-organization of teaching process.

\section{OVERVIEW OF PREVIOUS RESEARCH}

The results of numerous communication researches, both in the world (Measel and Mood, 1972; Furst and Amidon, 1965) and by us (Ševkušić-Mandić, 1991, Ševkušić-Mandić, 1992), show that a discrepancy between the condition in praxis and set objectives and aims of pedagogical and educational work exist. Teacher insufficiently knows the shapes and models with pupils' communication, as well as, developmental possibilities and needs of communication participants. Nenad Suzić (2003) lists 6 possible ways of communication (Teacher- class, teacher pupil, pupil - teacher, pupil-class, pupil-pupil, pupil-material) and stresses that the real image of teaching is reliably reflected by communication direction achieved in lesson. Predomination of teacher's appearance in lessons leaves less space for pupil to be leader, independent, free. Less than $2 \%$ of time for communication direction pupil-teacher is used. Flanders (1984) classified teacher's verbal communication during teaching process into 2 categories, which create emotional atmosphere in class, and he named one indirect, and the other direct teacher's impact.

\section{RESEARCH METHODOLOGY}

The problem of this research is teaching communication as permanent, current and thorough pedagogical and didactical question, which has motivated this kind of research. The entire history of pedagogical and didactical thought is permeated by the tendency of achievement of spontaneous interpersonal communicative relation in teaching or at least motivated communicative relation of its main actors.

The questions are placed: how much does communication takes place ( incidence, frequency), how much is the communication successful and is it equal in all directions, relation during the teaching processes of different school subjects, does a difference in communication achievement (failure), depending on school subjects, regarding the affiliation dependence to group of subjects, common educational and skills in general class teaching, exist.

The subject of this research is the determination of the incidence and successfulness of pedagogical communication regarding the 
communication direction (pupil- teacher, teacher - pupil and pupil pupil). Also, this research's aim is to determine the communication incidence and successfulness during the teaching of group of school subjects (common educational and skills) and to determine the relation of communications achievements regarding the type, that is, the group teaching subjects belongs to.

The problem nature and set research aim decided that this research has an empirical character. From set research aim and goal, the following research tasks arise:

To determine the incidence and successfulness of pedagogical communication towards the school subjects in general class teaching on relations teacher - pupil, pupil - teacher, pupil - pupil, during 300 teaching classes.

To determine whether a statistically relevant difference in the accomplishment and failure of communications towards teaching subject in general class teaching exists.

To determine whether a statistically relevant difference in the incidence and accomplishment of communications between common educational group of teaching subjects and skills exists.

In a research, conceptualized in this way, it is possible to set two hypothesis:

It is assumed that the communication is the most frequent and the most accomplished on relation teacher - pupil, given that in our schools the traditional concept of teaching, during which a one direction communication takes place, still dominates,

It is assumed that the communication is the most frequent and the most accomplished during the common educational subjects teaching (Serbian language, Maths, Science and Social Studies), that is, a statistically significant difference in incidence and accomplishment of communications during the common educational teaching exists.

Method applied in this research is chosen in accordance with problem nature, subject, aim and tasks of research, as well as, in accordance with the set hypothesis. The methods of observance, measurement and statistical method are used in the research. Research techniques are techniques of observance and notation.

For the needs of this research, a specially designed instrument for notation is used, in which observed cases are entered according to the set methodology. The instrument shows the seating pattern of pupils in the form of little circles. Before an observance, a time period of 20 minutes is set as , a time sample“. The direction and incidence of communication are 
observed. Before a observance, the circles for empty seats in the classroom are darkened by a pencil. Communicative units are, for example, a question and an answer or an action that one pupil does at the insistence of a teacher and vice versa, and they are noted by the sign (+) inside the circle, if they are initiated by the teacher. If there is no answer to the question asked, it is marked with the sign (-). Communication, initiated by the pupils, is marked on the external side, around a circular. The third direction of communications is pupil - pupil communication, which is marked with rounded plus or minus sign or with connecting these sign with arrows. Each instrument is processed separately, and, in the end, on the last instrument in analysis, the number of established communications and those which are only ,a communication attempt“ is summed. Then, they are arranged in three directions: from teacher towards pupil, from pupil towards teacher and from pupil to pupil, crossed inside of two communication categories, accomplished and unaccomplished.

The research sample covered elementary schools acroos The Serbian Republic, in Bijeljina, Brcko county, Samac, Modrica, Zvornik, Sekovici, Milici, Bratunac, Rogatica. The total of 300 teaching classes has been examined, 50 lessons of each teaching subjects: Serbian language, Maths, Science and Social Studies, Art, Music and Physical Education. The forthcoming table shows the sample structure according to number of observed classes in above mentioned elementary schools. Overall research sample makes 300 teaching classes, and out of that, 50 classes per different school subjects in general class teaching.

Table 1: Structure of research sample

\begin{tabular}{ll} 
School name, location & Number of observed classes \\
\hline Elementary school „Knez Ivo od Semberije“, Bijeljina & 52 \\
& \\
Elementary school „Sveti Sava“ Bijeljina & 34 \\
Elementary school "Vuk Karadzic“ Bijeljna & 54 \\
Elementary school “Jovan Ducic” & 20 \\
Elementary school, Brcko & 25 \\
Elementary school, Zvornik & 28 \\
Elementary school, Sekovici & 12 \\
Elementary school, Milici & 26 \\
Elementary school, Bratunac & 34 \\
Elementary school, Rogatica & 15 \\
\hline Total: & 300 \\
\hline
\end{tabular}

From Table 1, it can be seen that different number of teaching classes is observed in all mentioned schools. The biggest number of observed classes, in overall sample, was in elementary school „Knez Ivo 
od Semberije" in Bijeljina, which has the status of the biggest school in the Serbian Republic, with the biggest number of school sections and pupils. The class observance lasted for 5 weeks in March and April, 2016, in the first and second trimester of elementary school (from II to $\mathrm{V}$ grade). One of the teaching observance tasks was exploring interpersonal relations in the school section considering the nature of incidence and communication direction during the class, which is the most important task for this research.

\section{THE RESEARCH RESULTS AND DISCUSSION}

In this chapter, the significance of research in the area of pedagogical communication in general class teaching is highlighted from different aspects. Through the analysis and interpretation of data, we will get the results that will give the answers to defined tasks and confirm or reject set hypothesis.

During the research, that has been done in March and April in 2016, using specially designed constructed instrument for this type of recorded frequencies, we got results which are summed in the following table.

Table 2: Overall number of communications on all three relations towards the subjects

\begin{tabular}{|c|c|c|c|c|c|c|}
\hline $\begin{array}{l}\text { COMMON } \\
\text { EDUCATIONAL }\end{array}$ & $T-P$ & & $P-T$ & & $P-P$ & \\
\hline $\begin{array}{l}\text { GROUP OF SUBJECTS } \\
\text { AND SKILLS }\end{array}$ & + & - & + & - & + & - \\
\hline Serbian language & 376 & 99 & 169 & 34 & 164 & 46 \\
\hline Maths & 317 & 128 & 195 & 36 & 163 & 43 \\
\hline $\begin{array}{l}\text { Science and Social } \\
\text { Studies }\end{array}$ & 326 & 111 & 195 & 33 & 183 & 38 \\
\hline Art & 267 & 57 & 246 & 21 & 273 & 42 \\
\hline Music & 391 & 71 & 175 & 17 & 192 & 41 \\
\hline Physical Education & 323 & 67 & 205 & 46 & 238 & 62 \\
\hline $\begin{array}{l}\text { Overall achieved and } \\
\text { unachieved } \\
\text { communication }\end{array}$ & 2000 & 533 & 1185 & 187 & 1213 & 272 \\
\hline $\begin{array}{l}\text { Overall frequent } \\
\text { communication }\end{array}$ & 2533 & & 1372 & & 1485 & \\
\hline
\end{tabular}

Table 2 shows communication frequencies per teaching subjects, as well as per relations on which communication is developed and if it is developed, successful (+) or unsuccessful, failure (-).

Starting from the first set task of research, which was establishing the incidence and successfulness of pedagogical communication in 
general teaching classes on relations teacher-pupil, pupil-teacher and pupil-pupil, over 300 teaching lessons, in the next chart the obtained results are showed.

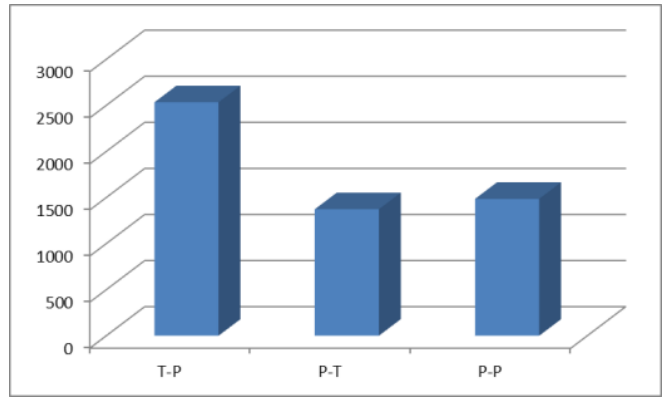

Chart 1: Communication incidence towards relations

Looking at the chart 1 , we see that communication on teacher pupil relation is the most frequent (2533), while on other two relations (pupil - teacher, pupil -pupil), communication occurred in significantly smaller number ( $\mathrm{p}-\mathrm{t}$ 1372, $\mathrm{p}-\mathrm{p}$ 1485). Using the percentage account of communication frequencies towards the relations we conclude that communication on teacher - pupil is the most frequent one $(45 \%)$, while on pupil -teacher $27 \%$ and on pupil- pupil relation $28 \%$.

Then, we determined the successfulness, achievement of communication on relations and concluded that communication on teacher - pupil relation, except of being the most frequent, is also the most achieved compared to the communications on other two relations, which the following chart shows.

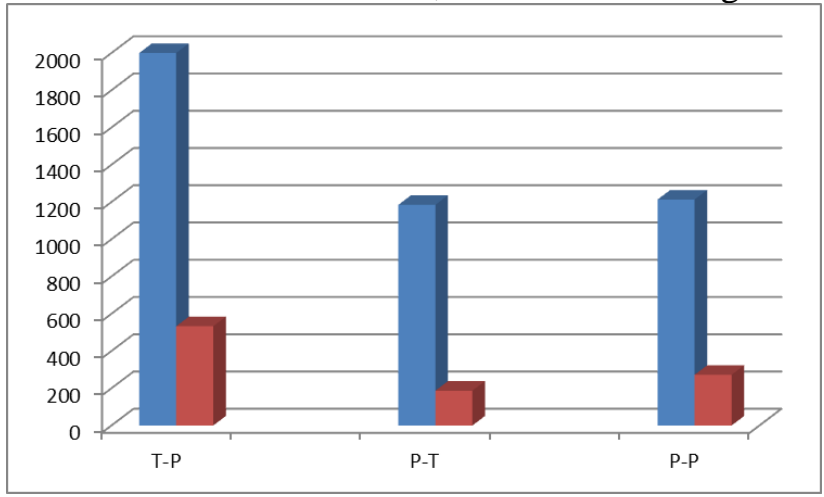

Chart 2: The achievement of communications towards relations

Observing the value of achieved and unachieved communications in mentioned chart 3 , we see that communication on teacher - pupil relation is considerably more achieved (2000) compared to the number of 
achieved communications on pupil - teacher relation (1185) and on pupilpupil relation (1213). Also, from the same chart, it can be seen that the unachieved communication on teacher - pupil relation is considerably bigger (533), while the number of unachieved communications on other two relations are much smaller, pupil - teacher 187 and pupil - pupil 272.

Considering that it is about frequencies which tell us about real number of achieved communications, we decided to apply nonparametric $\mathrm{Xi}$ square test. This test served in our work for checking the set hypothesis, in which we claimed that there exists statistically significant difference in the achievement of communications toward the relations in general class teaching. The most successful, the most achieved communication occurs on teacher - pupil relation, during the class of all observed teaching subjects (Serbian language, Maths, Science and Social Studies, Music, Art and Physical Education).

For the achievement of set research tasks, we divided Table 2 into two tables (successful/achieved and unsuccessful/unachieved communications), upon which we will perform $\mathrm{X}^{2}$ test for contingency table.

For calculating Xi square test, the software SSP (Smith's Statistical Package) has been used.

Firstly, we will formulate null and alternative hypothesis:

$\mathrm{X}_{\mathrm{O}^{-}}$the achievement, successfulness of communication is independent of the subject type,

$\mathrm{X}_{1^{-}}$there is dependence in communications achievement per relations between teaching subject.

In the following tables, empirical (observed) and theoretical communications frequencies, which are got by dividing the total of summation of column and row, in which the cell is, with the total summation of all frequencies of columns and rows.

Table 3: Achieved/successful communication per relations towards teaching subjects (empirical values)

\begin{tabular}{lllll}
\hline & T-P & P-T & P-P & Total: \\
\hline Serbian language & 376 & 169 & 164 & 709 \\
Maths & 317 & 195 & 163 & 675 \\
Science and Social Studies & 326 & 195 & 183 & 704 \\
Art & 267 & 246 & 273 & 786 \\
Music & 391 & 175 & 192 & 758 \\
Physical education & 323 & 205 & 238 & 766 \\
Overall communication achievement on relation: & 2000 & 1185 & 1213 & 4398 \\
\hline
\end{tabular}


Table 4: Achieved/successful communications per relations towards teaching subjects(theoretical values)

\begin{tabular}{lllll}
\hline & T-P & P-T & P-P & Total: \\
\hline Serbian language & 322,384 & 191,033 & 195,548 & 709 \\
Maths & 306,958 & 181,872 & 186,170 & 675 \\
Science and Social Studies & 320,146 & 189,686 & 194,168 & 704 \\
Art & 357,435 & 211,780 & 216,784 & 786 \\
Music & 344,702 & 204,236 & 209,062 & 758 \\
Physical Education & 348,340 & 206,392 & 211,268 & 766 \\
$\begin{array}{l}\text { Overall communication achievement on } \\
\text { relation: }\end{array}$ & 2000 & 1185 & 1213 & 4398 \\
\hline
\end{tabular}

Further procedure implies calculating the value of test statistics using SPSS software.

Test was conducted with $95 \%$ of reliability and calculated value of $\chi 2$ test is 81,612. From critical value table $\chi 2$ disposition with a degree of freedom $\mathrm{df}=(\mathrm{r}-1)(\mathrm{c}-1)=(6-1)(3-1)=10$, where $\mathrm{r}$ represents number of rows and c number of columns of observed contingency table, $\mathrm{X}^{2}{ }_{0}$ is 18,307 . Comparing the obtained value to the value from $\mathrm{X}^{2}$ disposition, we come to the conclusion that null hypothesis cannot be accepted, thus we reject it and accept the set alternative hypothesis, that is, that a significant difference in the achievement of communication per relations, depending on teaching subjects, exists.

Based on collective Table 3 with data about achieved, successful communication per relations towards teaching subjects, the conducted chart is showed.

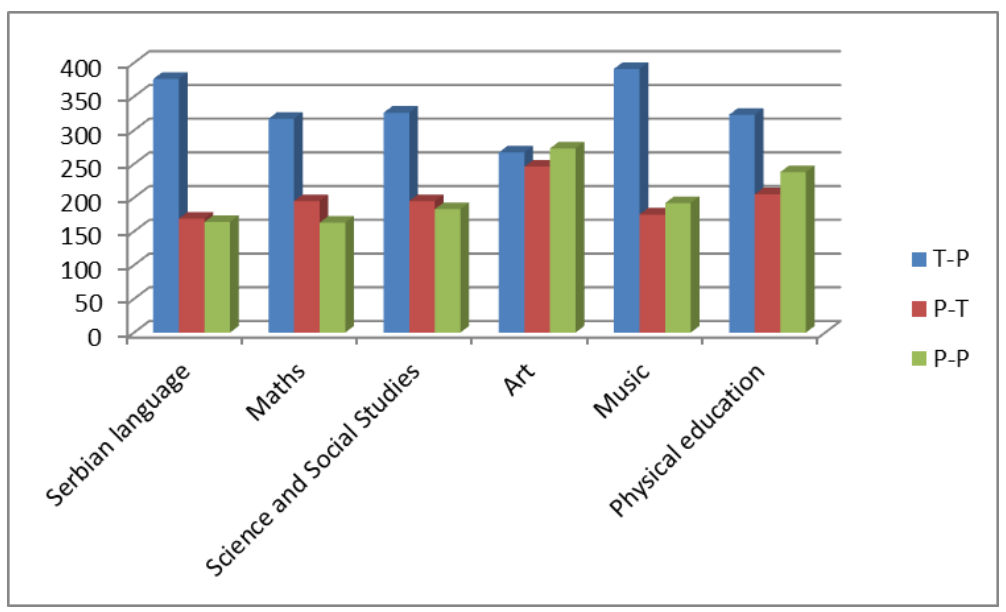

Chart 3:Achieved communications per relations towards teaching subjects 
Observing the Chart 3, it is obvious that the communications frequency is the most expressed on teacher - pupil relation, in all teaching subjects.

We applied the same test for unachieved, unsuccessful communications. Data are showed in the following table. Before calculating, we set null and alternative hypothesis.

$\mathrm{X}_{0}$ - underachievement, unsuccessfulness of communications is independent of teaching subject type, and

$\mathrm{X}_{1}$ - there is dependence in underachievement of communications on relations towards subjects, that is, on certain subjects, more communications are not achieved than on other.

In the following tables, empirical and theoretical frequencies of unachieved communications, on relations towards subjects, are showed.

Table 5: Unachieved/unsuccessful communications per relations towards teaching subjects (empirical values)

\begin{tabular}{lllll}
\hline & T-P & P-T & P-P & Total: \\
\hline Serbian language & 99 & 34 & 46 & 179 \\
Maths & 128 & 36 & 43 & 207 \\
Science and Social Studies & 111 & 33 & 38 & 182 \\
Art & 57 & 21 & 42 & 120 \\
Music & 71 & 17 & 41 & 129 \\
Physical Education & 67 & 46 & 62 & 175 \\
Overall communication achievement on relation: & 533 & 187 & 272 & 992 \\
\hline
\end{tabular}

Table 6: Unachieved/unsuccessful communications per relations towards teaching subjects (theoretical values)

\begin{tabular}{lllll}
\hline & T-P & P-T & P-P & Total: \\
\hline Serbian language & 96,176 & 33,743 & 49,984 & 179 \\
Maths & 111,221 & 39,021 & 56,758 & 207 \\
Science and Social Studies & 97,788 & 34,308 & 49,903 & 182 \\
Art & 64,476 & 22,621 & 32,903 & 120 \\
Music & 69,311 & 24,318 & 35,371 & 129 \\
Physical Education & 94,027 & 32,989 & 47,984 & 175 \\
Overall communication achievement on relation: & 533 & 187 & 272 & 992 \\
\hline
\end{tabular}

Further procedure implies calculating the value of test statistics using SPSS software.

Test was conducted with $95 \%$ of reliability and calculated value of $\chi 2$ test is 34,6839 .

From critical value table of $\chi 2$ disposition with a degree of freedom df $=(r-1)(c-1)=(6-1)(3-1)=10$, where $r$ represents number of rows and $c$ number of columns of observed contingency table, $\mathrm{X}^{2}{ }_{0}$ is 18,307 . Comparing the obtained value to the value from $\mathrm{X}^{2}$ disposition, we come 
to the conclusion that null hypothesis cannot be accepted, thus we reject it and accept the alternative hypothesis, that is, that a significant difference in the underachievement and unsuccessfulness of communication per relations, depending on teaching subjects, exists.

Based on collective Table 5 with the data about unachieved, unsuccessful communication per relations towards teaching subjects, the conducted chart is showed.

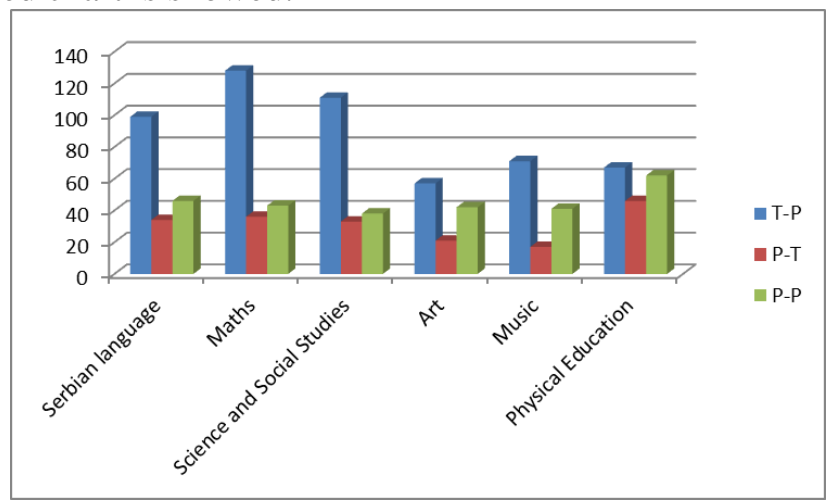

Chart 4: Unachieved, unsuccessful communications per relations

From Chart 4, it is obvious that the most unachieved communications in all teaching subjects is on the teacher- pupil relation. It is significant to mention another important data, observed from the chart, and it is the fact that besides the communications were the most unsuccessful on teacher - pupil relation, also the number of unsuccessful communications during teaching Serbian language and Music is considerably bigger than during teaching other subjects. We can assume that one of the factors for large number of unsuccessful communications is also teaching contents during mentioned subjects. Serbian language is teaching subject with exceptionally meaningful teaching contents, abundant in new information, while Music is teaching subject which is tied to personal affinity of pupil towards this kind of art.

Form Table 2, we disassembled data, obtained by research towards subjects group and achievement of communication on the same. We grouped teaching subjects into common educational group (Serbian language, Maths, Science and Social Studies) and skills group ( Music, Art, Physical Education). 
Table 7: The incidence and achievement of communications towards subjects groups ( empirical values )

\begin{tabular}{llll}
\hline Achieved/unachieved & + & - & Overall incidence: \\
\hline Common educational & 2088 & 568 & 2656 \\
group & & & \\
Skills & 2310 & 424 & 2734 \\
Total: & 4398 & 992 & 5390 \\
\hline
\end{tabular}

We made a chart from Table 7 , from which we will observe the relation between communications frequencies and subjects groups and their achievement or underachievement.

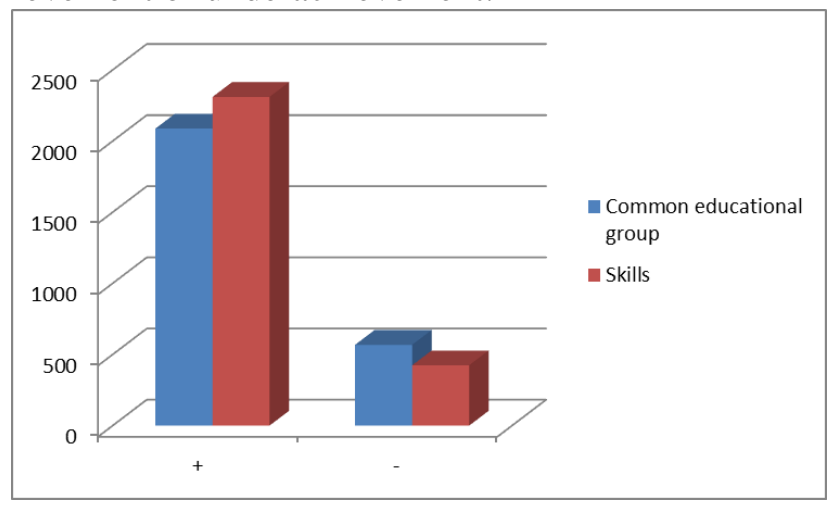

Chart 5: Achieved, unachieved communications towards subjects groups

From Chart 5, we note that the number of achieved communications during teaching skills is bigger (2310) compared to common educational subjects group (2088), while the number of unachieved communications is bigger during teaching common educational subjects(568) compared to teaching skills (424). Observing the frequencies of overall communication incidence on subjects groups, we see that during teaching skills the communication is more frequent (2734) compared to common education subjects group (2656).

We will test the incidence of achieved communications, using $\mathrm{X}^{2}$ test of incidence, towards two groups of subjects: common educational (Serbian language, Maths, Science and Social Studies) and skills (Art, Music, and Physical Education).

Before we set off our calculating, we set null and alternative hypothesis:

$\mathrm{X}_{0}$ - the structure of achievement, successfulness (achieved, successful/unachieved, unsuccessful) 
$\mathrm{X}_{1}$ - there exists significant deviation in the structure of communication achievement depending on subjects group

With the following table, we will show theoretical values of communications per groups of teaching subjects, as well as the successfulness's (+) and unsuccessfulness's (-) from which we will made value of $\mathrm{X}^{2}$ test.

Table 8: The incidence and achievement of communications towards subjects groups (theoretical values)

\begin{tabular}{llll}
\hline Achieved/unachieved & + & - & Overall incidence: \\
\hline Common educational & 2167,178 & 488,822 & 2656 \\
group & & & \\
Skills & 2230,822 & 503,178 & 2734 \\
Total: & 4398 & 992 & 5390 \\
\hline
\end{tabular}

SPSS software gave the following results: value of $\chi 2$ test is 30,937 and test was done with the $95 \%$ of precision. From critical value table $\chi^{2}$ disposition with a degree of freedom $\mathrm{df}=(\mathrm{r}-1)(\mathrm{c}-1)=(6-1)(3-1)=10$, where $\mathrm{r}$ represents number of rows and $\mathrm{c}$ number of columns of observed contingency table, $X^{2}$ is 3,841 . Since the given values of $X^{2}$ test is considerably bigger than tabular critical value, , we come to the conclusion that null hypothesis cannot be accepted, thus we reject it and conclude that there is significant difference in the structure of communication achievement depending on the group of teaching subjects.

This many large deviation in value of $\mathrm{X}^{2}$ test in the communication achievement towards the subject group, was expected, because the affiliation of teaching subjects, itself, to certain group is very noticeable. Common educational group of subjects, that is, teaching of Serbian language, Maths and Science and Social Studies is, because of the curriculum width as well as of bigger annual lessons number of these subjects, more dynamic, it demands the appliance of different teaching forms and methods and demands larger pupil engagement during classes. Teaching contents are more interesting, abundant in large number of new information, applicable in everyday life and put pupil in more active position.

\section{CONLUSION}

Communication in general class teaching is very complicated process and it demands from teachers wide general education as well as excellent knowledge of profession. In theoretical part of this paper, we defined the term pedagogical communication, which means transfer, conveying, exposure, acceptance, that is, message interchange as well as 
establishing relations, communication, the ways in behaviour among participants (factors) in pedagogical and educational work and learning process. Considering the specifics of communication process, it can be said that the efficiency of pedagogical communication, greatly, depends on teachers abilities to put pupil into position of active participant of pedagogical and educational process.

It is known that our school is not efficient enough, that traditional way of work, which refers to passive role for pupils, poor quality and usually one-way communication, still, has not been overcome. The results of this research, will contribute to improvement and modernization of pedagogical communication efficiency in our country.

The research that has occurred in March and April, 2016 in elementary schools across the Serbian Republic, gave us clear results for further promotion of pedagogical communication in general class teaching. Starting from the set tasks of research, we got numerous results which give us clear current state in teaching, tied to the communication area.

By analysis and interpretation of results, we came to the conclusion that communication in general class teaching is mostly one-way communication, it takes place mostly on teacher- pupil relation, $45 \%$ of incidence and achievement of communication on this relation. With this result, we confirmed our first set hypothesis, when we claimed that communication on teacher - pupil relation is the most incident and the most achieved.

There is also a significant difference considering the successfulness, that is, the communication achievement towards subjects on relations. Using nonparametric X2 test we confirmed the significance, where we got value of 81,612 , which proves to us that there is a difference in communication achievement depending on relation it occurred on.

Also, we compared the values of underachievement, unsuccessfulness of communication on relations towards subjects. Using the same test, we observed statistical difference where the obtained value was 34, 6839, which is far above the set border value. With this, we proved that there is a difference in the communication underachievement, depending on relations.

With second hypothesis, we claimed that the communication is more incident and more achieved during the classes of general educational subjects (Serbian language, Maths, Science and Social Studies), that is, there exists statistically significant difference in the communication 
incidence and achievement during teaching common educational subjects. We confirmed that the communication frequency, during teaching skills, is slightly bigger compared to common educational subject group, but that also, there exists statistically significant difference in the achievement and incidence of communication towards subject groups. With this conclusion, we partly confirmed second hypothesis.

We hope that this research will, to some measure, help to future explorers $\mathrm{f}$ this area, but also to teachers who can use these results in praxis.

\section{REFERENCES}

Brajša, P. (1994). Pedagoška komunikologija. Zagreb: Školske novine.

Flanders, N.A. (1984). Interaction Analysis in the Classroom: A Manual for Observers. Ann Arbor, MI: University of Michigan: School of Education.

Furst, N., \& Amidon, E. (1965). Teacher-pupil interaction patterns in the teaching of reading in the elementary school. The Reading Teacher, 18(4), 283-287. Retrieved from http://www.jstor.org/stable/20197913

Graorac, I. (1995). Vaspitanje i komunikacija: Mogućnosti osvešćivanja pedagogije. Novi Sad: Matica srpska.

Ivić, I. (1978). Čovek kao Animal symbolicum: Razvoj simboličkih sposobnosti. Beograd: Nolit.

Measel, W., \& Mood, D.W. (1972). Teacher verbal behavior and teacher and pupil thinking in elementary school. The Journal of Educational Research, 66(3), 99-102.

doi:10.1080/00220671.1972.10884418 OFF-SET.

Musić, H., \& Muratović, A. (2010). Komunikacija u nastavi. Tuzla:

Simeunović, V., \& Spasojević, P. (2005). Savremene didaktičke teme. Bijeljina: Pedagoški fakultet.

Suzić, N. (2005). Pedagogija za XXI vijek. Banja Luka: TT- Centar.

Ševkušić-Mandić, S. (1991). Oblici verbalne komunikacije između učitelja i učenika. Zbornik Instituta za pedagoška istraživanja, 23, 232-260.

Ševkušić-Mandić, S. (1992). Stil ponašanja učitelja i socijalnoemocionalna klima u odeljenju. Nastava i vaspitanje, 41(3), 290-302.

Vilotijević, M. (2000). Predmet didaktike. Beograd: Naučna knjiga. 


\title{
ПЕДАГОШКА КОМУНИКАЦИЈА - ОСТВАРЕНОСТ И УЧЕСТАЛОСТ У РАЗРЕДНОЈ НАСТАВИ
}

\author{
Данијела С. Панић ${ }^{3}$, Драгана Д. Лазић ${ }^{1 *}$, Љиљана Љ. Митровић ${ }^{2}$
}

Сажетак: Овај рад се бави педагошком комуникацијом, односно учесталости и остварености комуникације у разредној настави. Циљ истраживања је утврђивање учесталости и успјешности педагошке комуникације с обзиром на смјер комуникације (ученик - наставник, наставник - ученик и ученик - ученик). Такође, ово истраживање има за циљ да утврди учесталост и успјешност комуникација током наставе група предмета (опште-образовних и вјештина) и да утврди однос остварености комуникација с обзиром на врсту, тј. Групу којој наставни предмет припада. Природа проблема и постављени циљ истраживања опредјелили су да ово истраживање има емпиријски карактер. Из постављеног предмета и циља истраживања произилазе следећи задаци истраживања: утврдити учесталост и успјешност педагошке комуникације према наставним предметима у разредној настави на релацијама наставник-ученик, ученик-наставник, ученик-ученик, током 300 наставних часова; утврдити постоји ли статистички значајна разлика у остварености и неоствареност комуникација према наставним предметима на релацијама у разреној настави; утврдити постоји ли статистички значајна разлика у учесталости и остварености комуникације између опште-образовне групе наставних предмета и вјештина.

Истраживање је вршено методом посматрања, биљежења, кориштен је посебно конструисан инструмент за ову врсту података и истраживања. Резултати показују да је комуникација најучесталија и најостваренија на релацији наставник-ученик, као и да оствареност и неоствареност комуникација зависи од врсте наставног предетета. Пошто је педагошка комуникација изузетно битан сегмент у васпитно-образовном процесу у нашим школама, овај рад пружа корисна сазнања за даље проучавање, унапређење и усавршавање комуникације у настави.

Кључне ријечи: основна школа; постигнуће; наставни предмет; разредна настава; педагошка комуникација

\footnotetext{
${ }^{3}$ simeunovic.danijela@gmail.com, 1*draganaldj@gmail.com, ОШ „Кнез Иво од Семберије", Бијељина, Република Српска, БиХ

${ }^{2}$ mitroviclj@spinter.net, ОШ „Вук Караџић“, Забрђе, БиХ
} 


\title{
ПЕДАГОШКА КОМУНИКАЦИЈА - ОСТВАРЕНОСТ И УЧЕСТАЛОСТ У РАЗРЕДНОЈ НАСТАВИ
}

\author{
Данијела С. Панић
}

Сажетак: Овај рад се бави педагошком комуникацијом, односно учесталошћу и оствареношћу комуникације у разредној настави. Циљ истраживања је утврђивање учесталости и успјешности педагошке комуникације с обзиром на смјер комуникације (ученик - наставник, наставник - ученик и ученик - ученик). Такође, ово истраживање има за циљ да утврди учесталост и успјешност комуникација током наставе група предмета (опште-образовних и вјештина) и да утврди однос остварености комуникација с обзиром на врсту, тј. групу којој наставни предмет припада. Природа проблема и постављени циљ истраживања опредјелили су да ово истраживање има емпиријски карактер. Из постављеног предмета и циља истраживања произилазе следећи задаци истраживања: утврдити учесталост и успјешност педагошке комуникације према наставним предметима у разредној настави на релацијама наставник-ученик, ученик-наставник, ученик-ученик, током 300 наставних часова; утврдити постоји ли статистички значајна разлика у остварености и неоствареност комуникација према наставним предметима на релацијама у разреној настави; утврдити постоји ли статистички значајна разлика у учесталости и остварености комуникације између опште-образовне групе наставних предмета и вјештина.

Истраживање је вршено методом посматрања, биљежења, кориштен је посебно конструисан инструмент за ову врсту података и истраживања. Резултати показују да је комуникација најучесталија и најостваренија на релацији наставник-ученик, као и да оствареност и неоствареност комуникација зависи од врсте наставног предмета. Пошто је педагошка комуникација изузетно битан сегмент у васпитно-образовном процесу у

\footnotetext{
${ }^{1}$ simeunovic.danijela@gmail.com, 1*draganaldj@gmail.com, ОШ „Кнез Иво од Семберије", Бијељина, Република Српска, БиХ

${ }^{2}$ mitroviclj@spinter.net, ОШ „Вук Караџић“, Забрђе, БиХ
} 
нашим школама, овај рад пружа корисна сазнања за даље проучавање, унапређење и усавршавање комуникације у настави.

Кључне ријечи: основна школа; постигнуће; наставни предмет; разредна настава; педагошка комуникација

\section{УВОД}

Педагошка комуникација у великој мјери представља израз суштинског схватања наставе, њене организације, примјењених дидактичких система наставе, постављених циљева и задатака, руководећих принципа и кориштених метода и облика рада. Ефикасност васпитно-образовног процеса у настави у великој мјери зависи од успостављене комуникације, интеракције и односима међу непосредним учесницима тог процеса, а посљедица тога је стварање одређене психолошке, социјално-емоционалне, комуникацијске климе, која може бити мање или више погодна за успјешан рад. Комуникација у настави омогућава повезано дјеловање наставника и ученика, ученика и ученика, поучавања и учења. У њеној основи увијек се налази неки садржај, информација која се посредује, с једне, те прима и прерађује, с друге стране, гдје наставник и ученик непрестано мијењају улоге.

Савремена настава представља облик међусобног дјеловања и сарадње наставника и ученика. Ова сарадња се остварује као њихова узајамна интеракција и комуникација. Због тога је потребно да наставник зна како тече и функционише комуникација у настави, колико међусобно сарађују наставници и ученици, који типови вербалних комуникација се међу њима остварују и каква је њихова структура. Васпитно-образовни процес у савременој школи на кључно мјесто ставља комуникацију и однос између ученика и наставника. Комуникација одражава концепцију васпитања гдје је ученик објекат или субјекат, или обоје истовремено, а наставник од функције аутократског руководиоца до усмјеривача, сарадника, савјетника итд.

Један од начина за осавремењавање, усавршавање и подизање ефикасности наставе јесте управо расвјетљавање значаја педагошке комуникације и њено теоријско и емпиријско проучавање. На овај начин доћи ће се до нових практичних знања и закључака. С обзиром на актуелност теме и њен велики значај у настави, ми ћемо се у овом раду бавити испитивањем тренутног стања у основним школама о 
комуникацијском сегменту наставе, о учесталости, остварености комуникације на релацијама на којима се та комуникација остварује.

Испитивањем се желе утврдити учесталост и оствареност педагошке комуникације на релацијама наставник-ученик, ученикнаставник и ученик-ученик током извођења наставе српског језика, математике, природе и друштва као групе опште-образовних предмета и током извођења наставе ликовне културе, музичке културе, физичког васпитања као групе вјештина. Такође, ово истраживање има за циљ да утврди учесталост и успјешност комуникација током наставе група предмета (опште-образовних и вјештина), као и однос остварености, успјешности и неостварености, неуспјешности између њих.

Остваривањем задатака и потврђивањем или оповргавањем хипотеза овог истраживања, очекују се резултати који ће дати јасну слику о тренутној учесталости и остварености комуникација у настави. Поставиће свим учесницима васпитно-образовног процеса, наставницима и ученицима обавезу да перманентно унапређују и усавршавају комуникацију током наставе ради што потпунијег остваривања циљева и исхода наставних планова прописаних за све наставне предмете.

\section{КОМУНИКАЦИЈА}

Данас је у све чешћој употреби појам комуникације. Цјелокупна рана социјалност дјетета свједочи да постоји снажна мотивација дјетета за комуникацијом (Ивић, 1978:171). Код дјетета се већ у најранијем периоду јављају различити облици интеракције са околином, односно различити системи понашања у које спадају „перцепција људског лика и гласова људског говора, способност успостављања социјално-емоционалних веза и појава везаности за одређене особе, рана невербална двосмјерна комуникација између дјетета и мајке (Граорац, 1995:121). Појам комуникације потиче од латинске ријечи comunicare што значи учинити општим (Педагошки лексикон, 1996). У овој дефиницији увиђа се да је комуникација социјални акт и да је она двосмјерна. Ако појам комуникације схватимо у ширем значењу онда садржаји комуникације могу бити и материјална добра, енергија па чак и социјални односи. Процес размјене идеја, мисли и осјећања између двије или више особа, који почиње са одређеном свјесном или подсвјесном намјером и доводи 
до интеракције, разумијевања, повезивања и утицања, као и повећања сазнања његових учесника чини појам педагошке комуникације (Симеуновић, 2009:296).

Педагошка комуникација подразумијева и обуку за комуникацију, односно развијање способности једне стране, тј. ученика, да комуницира са другом страном или извором информација. Основни циљ је помоћи ученику да развије способности за успјешну и самосталну комуникацију са другим људима и са медијима комуникације. Сузић (2005) под појмом педагошка комуникација подразумијева преношење, саопштавање, излагање, примање, тј. размјена порука као и успостављање односа, споразумијевање, средства и начин опхођења међу учесницима у васпитно-образовном процесу и процесу учења. Педагошка комуникација важан је сегмент педагошког рада и услов за постизање квалитетне школе. Комуникација у школи треба да буде јасна, гласна и разумљива свим учесницима комуникације, она је уједно и идраз осјећања код ученика и директно утиче на његову мотивацију, формирање позитивног односа према раду, развијању свијести о потреби учења и на самом крају развијању свијести о самокритичности. Проучавајући литературу о настави и комуникацији у настави, наилази се на разне класификације. Према Симеуновићу педагошка комуникација се разврстава на основу три критеријума и то на основу броја учесника, с обзиром на начин комуницирања и с обзиром на средства комуницирања (Симеуновић, 2005:297). На основу броја учесника комуникација се дијели на интраперсоналну (унутрашњи говор), интерперсоналну (комуникација између двије особе), групну (комуникација вођена у мањим групама до тридесет учесника) и јавну (обраћање великом броју људи, углавном је једносмјерна). Вилотијевић (2000) наводи да у васпитању и образовању разликујемо следеће врсте комуникације: персонална и аперсонална; вербална и невербална; једносмјерна и двосмјерна; непосредна и посредна; и ауторитарна и демократска комуникација. Брајша (1994) сматра како разговор с учитељем активира и развија мозак ученика те се развија и обликује ученикова личност. Учитељ треба знати слушати ученика те разговор између њих треба бити двосмјеран.

Наставу (разредну и предметну) као континуирани васпитнообразовни и комуникацијски процес чини скуп фактора без којих она не би постојала. Дуго времена се сматрало да факторе наставе чине ученик, наставник и наставни садржаји, који се налазе у 
међузависном односу, тј. у такозваном „дидактичком троуглу“. У стручној и научној литератури постоји различита класификација фактора наставе а самим тим и фактора комуникације Најприхватљивија подјела је на посредне и непосредне факторе (Мусић, 2010:46). Непосредни фактори комуникације су: ученик, наставник, наставни садржаји и комуникацијска средства и помагала у настави, а у посредне факторе комуникације се убрајају особине наставника, стил рада наставника, позиција ученика и наставника у процесу наставе, одјељенска клима и микроорганизација процеса наставе.

\section{ПРЕГЛЕД ДОСАДАШЬИХ ИСТРАЖИВАЬА}

Резултати бројних истраживања комуникације како у свијету (Measel and Mood, 1972; Furst \& Amidon, 1965) тако и код нас (Шевкушић-Мандић, 1991, Шевкушић-Мандић 1992) показују да постоји раскорак између стања у пракси и постављених циљева и задатака васпитно-образовног рада. Наставници недовољно познају облике и моделе комуникације са ученицима, као и развојне могућности и потребе учесника комуникације. Ненад Сузић (2003) наводи 6 могућих смјерова комуникације (наставник-одјељење, наставник-ученик, ученик-наставник, ученик-одјељење, ученикученик, ученик-градиво) и истиче да стварну слику наставе поуздано одржава смјер комуникације остварен на часу. Предоминација наставниковог наступа на часовима оставља мало простора ученику да он буде водитељ, самосталан, слободан. У настави се користи мање од $2 \%$ времена на смјер комуникације ученик-наставник. Фландерс (Flanders, 1984) је наставникову вербалну комуникацију у наставном процесу квалификовао у 2 категорије, које креирају емоционалну климу у разреду, од којих је једну назвао индиректним, а другу директним наставниковим утицајем.

\section{МЕТОДОЛОГИЈА ИСТРАЖИВАњА}

Проблем овог истраживања је комуникација у настави као трајно, актуелно и темељно педагошко и дидактичко питање које је и мотивисало овакво истраживање. Цјелокупна историја педагошке и дидактичке мисли прожета је тенденцијом остваривања спонтаног интерперсоналног комуникацијског односа у настави или барем мотивисаног комуникацијског односа њених главних актера. 
Постављају се питања: колико се одвија комуникација (учесталост, фреквенција), колико је комуникација успјешна и да ли је равноправна у свим смјеровима, релацијама током извођења наставе различитих наставних предмета, постоји ли разлика у остварености (неостварености) комуникација у зависности од наставних предмета, односно зависности припадности групи предмета, опште - образовних и вјештина у разредној настави.

Предмет овог истраживања се односи на утврђивање учесталости и остварености педагошке комуникације на свим релацијама током извођења наставе српског језика, математике, природе и друштва као групе опште-образовних предмета и током извођења наставе ликовне културе, музичке културе, физичког васпитања као групе вјештина.

Циљ истраживања је утврђивање учесталости и успјешности педагошке комуникације с обзиром на смјер комуникације (ученик наставник, наставник - ученик и ученик - ученик). Такође, ово истраживање има за циљ да утврди учесталост и успјешност комуникација током наставе група предмета (опште-образовних и вјештина) и да утврди однос остварености комуникација с обзиром на врсту, тј. групу којој наставни предмет припада.

Природа проблема и постављени циљ истраживања опредјелили су да ово истраживање има емпиријски карактер.

Из постављеног предмета и циља истраживања произилазе следећи задаци истраживања:

-утврдити учесталост и успјешност педагошке комуникације према наставним предметима у разредној настави на релацијама наставник-ученик, ученик-наставник, ученик-ученик током 300 наставних часова;

-утврдити постоји ли статистички значајна разлика у остварености и неоствареност комуникација према наставним предметима на релацијама у разреној настави;

-утврдити постоји ли статистички значајна разлика у учесталости и остварености комуникације између опште-образовне групе наставних предмета и вјештина.

У овако конципираном истраживању могуће је поставити двије хипотезе:

Претпоставља се да је комуникација најучесталија и најоставренија на релацији наставник-ученик с обзиром на то да у 
нашим школама још увијек доминира традиционални концепт наставе током које се одвија једносмјерна комуникација,

Претпоставља се да је комуникација учесталија и остваренија током наставе опште-образовних предмета (српског језика, математике и природе и друштва) тј. да постоји статистички значајна разлика у учесталости и остварености комуникација током наставе опште-образовних предмета.

Метода примјењена у овом истраживању је одабрана у складу са природом проблема, предметом, циљем и задацима истраживања, као и у складу са постављеним хипотезама. У истраживању је кориштена метода посматрања, метода мјерења, статистичка метода. Истраживачке технике су техника посматрања и биљежења.

За потребе овог истраживања кориштен је посебно контруисан инструмент за биљежење у коме се према задатој методологији уносе опажени случајеви. Инструмент приказује распоред сједења ученика у виду кружића. Прије посматрања се одређује временски интервал у трајању од 20 минута као „временски узорак“. Посматра се смјер и учесталост комуникација. Прије посматрања кружићи за празна мјеста у учионици се затамне оловком. Комуникацијске јединице су, примјера ради, питање и одговор или акција коју изврши један ученик на захтјев наставника и обрнуто, а биљеже се знаком плус (+) унутар круга ако су инициране од стране наставника. Уколико није било одговора на постављено питање, то се означава знаком минус (-). Комуникација коју су иницирали ученици биљежи се на спољној страни, око кружнице. Трећи смјер комуникација је комуникација ученик-ученик што се означава заокруженим знаком плус или минус и повезивањем ових знакова стрелицама. Сваки инструмент се обрађује засебно, а на крају се на последњем инструменту у анализи се сумира број успостављених комуникација и оних које су „покушај комуникације“, а затим се разврставају на три смјера: од наставника према ученику, од ученика према наставнику и од ученика према ученику, укрштени унутар двије категорије комуникација, остварене и неостварене.

Узорак истраживања је обухватио основне школе широм Републике Српске, у Бијељини, Брчком, Шамцу, Модричи, Зворнику, Шековићима, Милићима, Братунцу, Рогатици. Посматрано је укупно 300 наставних часова у разредној настави и то по 50 часова сваког наставног предмета: српски језик, математика, природа и друштво, ликовна култура, музичка култура и физичко васпитање. Наредном 
табелом је приказана структура узорка према броју посматраних часова у наведеним основним школама. Укупан узорак истраживања чини 300 наставних часова, од тога по 50 часова различитих наставних предмета у разредној настави.

Табела 1: Структура узорка истраживања

\begin{tabular}{ll} 
Назив школе, мјесто & Број посматраних часова \\
\hline $\begin{array}{l}\text { Основна школа „Кнез Иво од } \\
\text { Семберије“, Бијељина }\end{array}$ & 52 \\
$\begin{array}{l}\text { Основна школа „Свети Сава“, } \\
\text { Бијељина }\end{array}$ & 34 \\
Основна школа „Вук Караџић“, & 54 \\
Бијељина & \\
Основна школа „Јован Дучић“, & 20 \\
Основна школа , Брчко & 25 \\
Основна школа , Зворник & 28 \\
Основна школа , Шековићи & 12 \\
Основна школа , Милићи & 26 \\
Основна школа , Братунац & 34 \\
Основна школа, Рогатица & 15 \\
\hline Свега: & 300 \\
\hline
\end{tabular}

У Табели 1 види се да је у свим наведеним школама посматран различит број наставних часова. Највећи број посматраних часова у укупном узорку је био у Основној школи „Кнез Иво од Семберије“ у Бијељини која има статус највеће школе у Републици Српској, са највећим бројем одјељења и ученика. Посматрање наставе трајало је 5 седмица у периоду мјесеца марта и априла 2016. године, у првој и другој тријади основне школе (од II до V разреда). Један од задатака посматрања наставе био је упознавање интерперсоналних односа у одјељењу у погледу природе учесталости и смјера комуникација за вријеме наставе, што је за ово истраживање и најважнији задатак.

\section{РЕЗУЛТАТИ ИСТРАЖИВАЊА И ДИСКУСИЈА}

У овом поглављу је са различитих аспеката наглашен значај истраживања на подручју педагошке комуникације у разредној настави. Кроз анализу и интерпретацију података доћи ће се до резултата који ће дати одговоре на дефинисане задатке и потврдити или одбацити постављене хипотезе.

Током истраживања које је обављено у марту и априлу 2016. године и кориштења посебно конструисаног иструмента за овакав 
вид евидентирања фреквенција, дошли смо до података који су сумирани и приказани у наредној табели.

Табела 2: Укупан број комуникација на све три релације према предметима

\begin{tabular}{|c|c|c|c|c|c|c|}
\hline \multirow{2}{*}{$\begin{array}{l}\text { ОПШТЕ- ОБРАЗОВНА } \\
\text { ГРУПА ПРЕДМЕТА И } \\
\text { ВЈЕШТИНА }\end{array}$} & \multicolumn{2}{|c|}{$H-Y$} & \multicolumn{2}{|c|}{$y-H$} & \multicolumn{2}{|c|}{$y-y$} \\
\hline & + & - & + & - & + & - \\
\hline Српски језик & 376 & 99 & 169 & 34 & 164 & 46 \\
\hline Математика & 317 & 128 & 195 & 36 & 163 & 43 \\
\hline Природа и друштво & 326 & 111 & 195 & 33 & 183 & 38 \\
\hline Ликовна култура & 267 & 57 & 246 & 21 & 273 & 42 \\
\hline Музичка култура & 391 & 71 & 175 & 17 & 192 & 41 \\
\hline Физичко васпитање & 323 & 67 & 205 & 46 & 238 & 62 \\
\hline $\begin{array}{l}\text { Укупна остварена и } \\
\text { наоставрена } \\
\text { комуникација: }\end{array}$ & 2000 & 533 & 1185 & 187 & 1213 & 272 \\
\hline $\begin{array}{l}\text { Укупна учестала } \\
\text { комуникација: }\end{array}$ & 2533 & & 1372 & & 1485 & \\
\hline
\end{tabular}

Табелом 2 су приказане фреквенције комуникација је по наставним предметима, као и релацијама на којима се комуникација одвијала и да ли је била остварена, успјешна (+) или неостварена, неуспјешна (-).

Полазећи од првог постављеног задатка истраживања који је био утврђивање учесталости и успјешности педагошке комуникације у разредној настави на релацијама наставник-ученик, ученикнаставник и ученик-ученик током 300 наставних часова, следећим графиконом приказујемо добијене резултате.

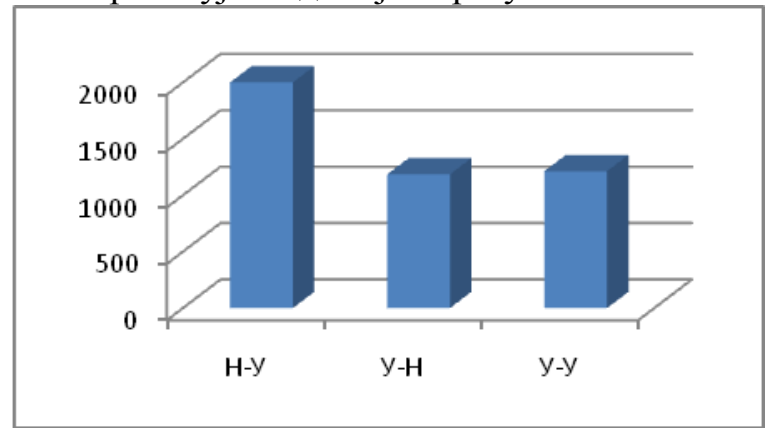

Графикон 1: Учесталост комуникације према релацијама

Посматрајући Графикон број 1 видимо да је комуникација на релацији наставник-ученик најучесталија (2533), док се на остале двије релације (ученик-наставник, наставник-ученик) комуникација 
одвијала у значајно мањем броју (у-н:1372, у-у:1485). Процентуалним рачуном забиљежених фреквенција комуникације према релацијама закључујемо да је комуникација на релацији наставник-ученик најучесталија (45\%), док је на релацији ученикнаставник $27 \%$ а на релацији ученик-ученик $28 \%$.

Затим смо утврдили успјешност, оствареност комуникација на релацијама и дошли до закључка да је комуникација на релацији наставник-ученик, поред тога што је учесталија, она је и остваренија у односу на број комуникација на друге двије релације, што нам наредни графикон и приказује.

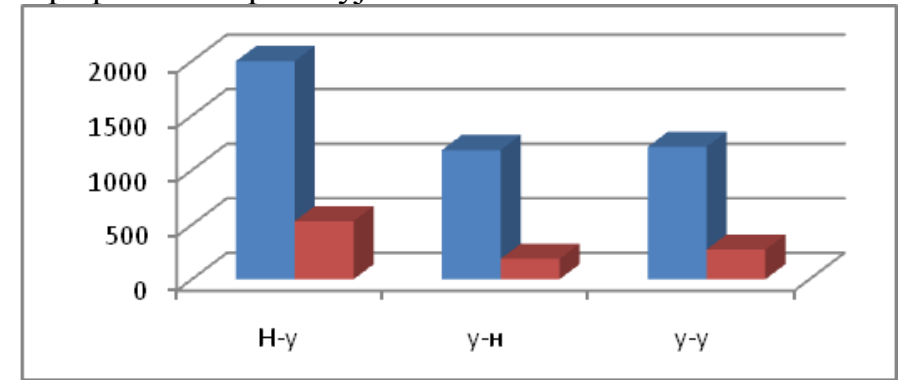

Графикон 2: Оствареност комуникација према релацијама

Посматрајући вриједност остварених и неостварених комуникација из наведеног Графикона број 3 видимо да је комуникација на релацији наставник-ученик знатно остваренија (2000) у односу на број остварених комуникација на релацији ученик-наставник (1185) и на релацији ученик-ученик (1213). Такође, се из истог графикона види да је неоставрена комуникација на релацији наставник-ученик значајно већа (533) док је број неостварених комуникација на остале двије релација много мањи, ученик-наставник 187 ученик- ученик 272.

С обзиром на то да се ради о фреквенцијама које нам говоре о стварном броју оставрених комуникација одлучили смо се за примјену непараметријског поступка Хи квадрат тест. Овај тест нам је у раду послужио за провјеру постављених хипотеза у којима смо тврдили да постоји статистички значајна разлика у остварености комуникација према релацијама у разредној настави и то да се најуспјешнија, најостваренија комуникација одвија на релацији наставник-ученик током наставе свих посматраних наставних предмета (срски језик, математика, природа и друштво, музичка, ликовна култура и физичко васпитање). 
За остваривање постављених задатака истраживања Табелу 2 смо подијелили у двије табеле (успјешне/остварене и неуспјешне/неостварене комуникације) на основу којих ћемо извести $\mathrm{X}^{2}$ тест за табелу контигенције.

За израчунавање Хи квадрат теста кориштен је софтвер SSP (Smith's Statistical Package).

Најприје ћемо формулисати нулту и алтернативну хипотезу:

$\mathrm{X}_{0}$ - оствареност, успјешност комуникација је независна од врсте предмета,

$\mathrm{X}_{1}$ - постоји зависност у остварености комуникација по ралација између наставних предмета.

Наредним табелама су приказане емпиријске (запажене) и теоријске фреквенције комуникација које се за дату ћелију добију тако што се производ збира колоне и збира реда у којој се посматрана ћелија налази подијели са укупним збиром свих фреквенција редова и колона.

Табела 3: Остварене/успјешне комуникаиије по релащијама према наставним предметима (емпиријске вриједности)

\begin{tabular}{lllll}
\hline & H-У & У-H & У-У & Укупн: \\
\hline Српски језик & 376 & 169 & 164 & 709 \\
Математика & 317 & 195 & 163 & 675 \\
Природа и друштво & 326 & 195 & 183 & 704 \\
Ликовна култура & 267 & 246 & 273 & 786 \\
Музичка култура & 391 & 175 & 192 & 758 \\
$\begin{array}{l}\text { Физичко васпитање } \\
\text { Укупна оствареност комуникација } \\
\text { на релацији: }\end{array}$ & 323 & 205 & 238 & 766 \\
& & 1185 & 1213 & 4398 \\
\hline
\end{tabular}

Табела 4: Остварене/успјешне комуникације по релацијама према наставним предметима (теоријске вриједности)

\begin{tabular}{|c|c|c|c|c|}
\hline & $\mathrm{H}-\mathrm{Y}$ & Y-H & $\mathbf{y}-\mathbf{y}$ & Укупно: \\
\hline Српски језик & 322,384 & 191,033 & 195,548 & 709 \\
\hline Математика & 306,958 & 181,872 & 186,170 & 675 \\
\hline Природа и друштво & 320,146 & 189,686 & 194,168 & 704 \\
\hline Ликовна култура & 357,435 & 211,780 & 216,784 & 786 \\
\hline Музичка култура & 344,702 & 204,236 & 209,062 & 758 \\
\hline Физичко васпитање & 348,340 & 206,392 & 211,268 & 766 \\
\hline $\begin{array}{l}\text { Укупна оствареност } \\
\text { комуникација на релацији: }\end{array}$ & 2000 & 1185 & 1213 & 4398 \\
\hline
\end{tabular}

Даљи поступак подразумијева израчунавање вриједности статистике теста SPSS софтвером. 
Тест је изведен уз 95\% поузданости и израчуната вриједност $\chi 2$ теста је 81,612. Из таблице критичне вриједности $\chi 2$ распореда уз степен слободе $\mathrm{df}=(\mathrm{r}-1)(\mathrm{c}-1)=(6-1)(3-1)=10$, гдје $\mathrm{r}$ представља број редова, а с број колона посматране табеле контигенције, $\mathrm{X}_{0}^{2}$ је 18,307 . Поређењем добијене вриједности са вриједношћу из таблице $\mathrm{X}^{2}$ распореда, долазимо до закључка да се не може прихватити нулта хипотеза, те је одбацујемо а прихватамо постављену алтернативну хипотезу тј. да постоји значајна разлика у остварености комуникација по релацијама у зависности од наставног предмета.

На основу збирне Табеле 3 са подацима о оствареним, успјешним комуникацијама по релацијама према наставним предметима приказан је изведени графикон.

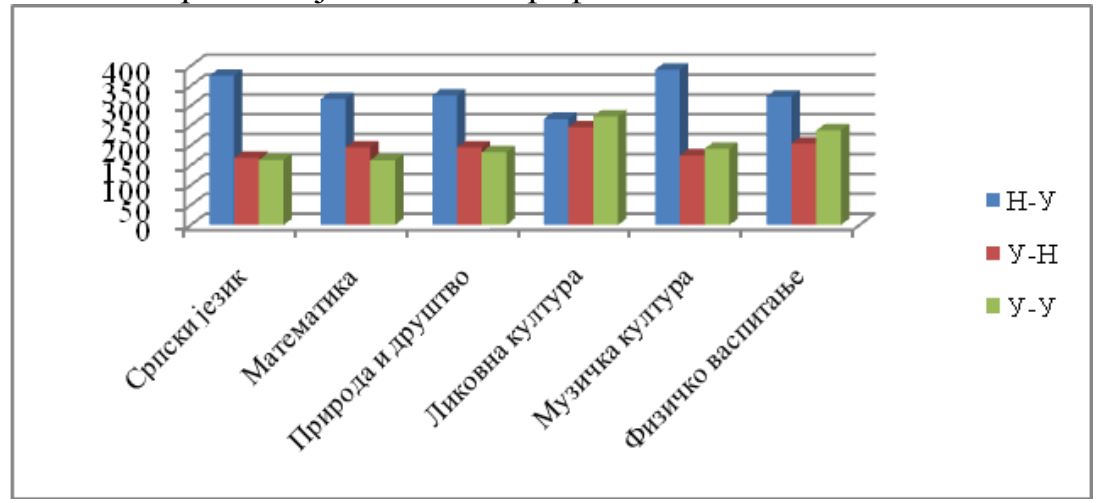

Графикон 3: Остварене комуникације по релацијама према наставним предметима

Посматрајући Графикон 3 очигледно је да је фреквенција комуникација најизраженија на релацији наставник-ученик на свим наставним предметима.

Исти тест смо примјенили и за неоставрене,неуспјешне комуникације. Подаци су приказани у следећој табели. Прије рачунања смо поставили нулту и алтернативну хипотезу:

$\mathrm{X}_{0}$ - неоствареност, неуспјешност комуникација је независна од врсте наставног предмета а

$\mathrm{X}_{1}$ - постоји зависност у неостваренсти комуникација на релацијама према предметима тј. на појединим предметима неостварено је више комуникација него на другим. 
Наредним табелама су приказане емпиријске и теоријске фреквенције неоставрених комуникација на релацијама према предметима.

Табела 5: Неостварене/неуспјешне комуникащије по релащијама према наставним предметима (емпиријске вриједности)

\begin{tabular}{lllll}
\hline & H- & У- & У- & Укупно: \\
& $\mathbf{y}$ & $\mathbf{H}$ & $\mathbf{y}$ & \\
\hline Српски језик & 99 & 34 & 46 & 179 \\
Математика & 128 & 36 & 43 & 207 \\
Природа и друштво & 111 & 33 & 38 & 182 \\
Ликовна култура & 57 & 21 & 42 & 120 \\
Музичка култура & 71 & 17 & 41 & 129 \\
$\begin{array}{l}\text { Физичко васпитање } \\
\text { Укупна оствареност комуникација } \\
\text { на релацији: }\end{array}$ & 57 & 46 & 62 & 175 \\
\hline
\end{tabular}

Табела 6: Неостварене/неуспјешне комуникације по релацијама према наставним предметима (теоријске вриједности)

\begin{tabular}{|c|c|c|c|c|}
\hline & H-Y & У-H & $\mathbf{y}-\mathbf{y}$ & Укупно: \\
\hline Српски језик & 96,176 & 33,743 & 49,984 & 179 \\
\hline Математика & 111,221 & 39,021 & 56,758 & 207 \\
\hline Природа и друштво & 97,788 & 34,308 & 49,903 & 182 \\
\hline Ликовна култура & 64,476 & 22,621 & 32,903 & 120 \\
\hline Музичка култура & 69,311 & 24,318 & 35,371 & 129 \\
\hline Физичко васпитање & 94,027 & 32,989 & 47,984 & 175 \\
\hline $\begin{array}{l}\text { Укупна оствареност } \\
\text { комуникација на релацији: }\end{array}$ & 533 & 187 & 272 & 992 \\
\hline
\end{tabular}

Даљи поступак подразумијева израчунавање вриједности статистике теста SPSS софтвером.

Тест је изведен уз 95\% поузданости и израчуната вриједност $\chi 2$ теста је 34,6839.

Из таблице критичне вриједности $\chi 2$ распореда уз степен слободе $\mathrm{df}=(\mathrm{r}-1)(\mathrm{c}-1)=(6-1)(3-1)=10$, гдје $\mathrm{r}$ представља број редова, а c број колона посматране табеле контигенције, $\mathrm{X}_{0}^{2}$ je 18,307 . Поређењем добијене вриједности са вриједношћу из таблице $\mathrm{X}^{2}$ распореда, долазимо до закључка да се не може прихватити нулта хипотеза па је одбацујемо, а прихватамо алтернативну хипотезу тј. да постоји значајна разлика у неостварености, неуспјешности комуникација по релацијама у зависности од наставног предмета.

На основу збирне табеле 5 са подацима о неоствареним, неуспјешним комуникацијама по релацијама према наставним предметима приказан је изведени графикон. 


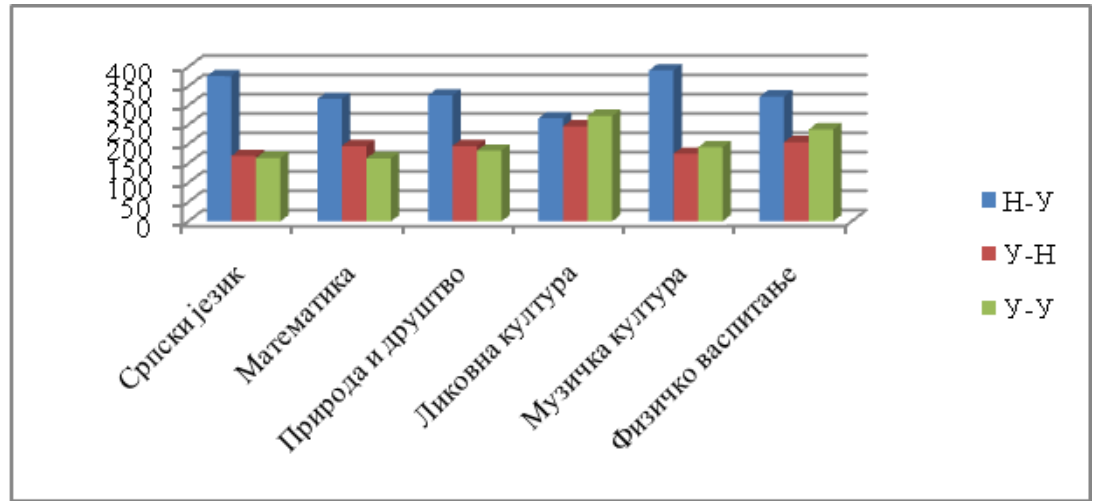

Графикон 4: Неуспјешне, неоставрене комуникације по релацијама

Из Графикона 4 очигледно је да на релацији наставник-ученик највише неостварених комуникација на свим наставним предметима. Значајно је напоменути још један битан податак уочен из графикона: поред тога што су комуникације најнеуспјешније на релацији наставник-ученик, такође је и број неуспјешних комуникација током наставе српског језика и музичке културе знатно већи поредећи са бројем неуспјешних комуникација током наставе осталих наставних предмета. Можемо претпоставити да је један од фактора за велики број неуспјешних комуникација и наставни садржаји током наведених часова. Српски језик је наставни предмет са изузетно садржајним наставним програмом, обилан новим информација, док је музичка култура наставни предмет који је везан и за лични афинитет ученика према овој врсти умјетности.

Из Табеле 2 смо разложили податке добијене истраживањем према групама предмета и остварености комуникација на истим. Наставне предмете смо груписали на опште-образовну групу којој припадају српски језик, математика, природа и друштво и групу вјештина којој припадају музичка и ликовна култура и физичко васпитање.

Табела 7: Учесталост и оствареност комуникација према групама предмета (емпиријске вриједности)

\begin{tabular}{llll}
\hline Остварена/неостварена & + & - & Укупна учесталост: \\
\hline Опште-образовна група & 2088 & 568 & 2656 \\
Вјештине & 2310 & 424 & 2734 \\
Укупно: & 4398 & 992 & 5390 \\
\hline
\end{tabular}


Из табеле 7 смо извели графикон из којег ћемо уочити однос фреквенција комуникација према групама предмета и њихову оствареност, односно неоствареност.

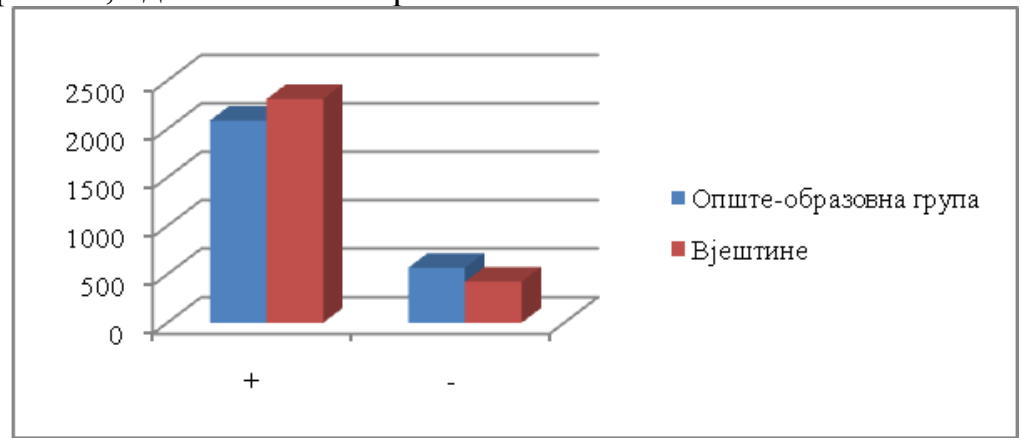

Графикон 5: Остварене, неостварене комуникације према групама предмета

Из Графикона 5 уочавамо да је број оставрених комуникација током наставе вјештина већи (2310) у односу на групу општеоброзовну групу предмета (2088), док је број неоставрених комуникација већи током наставе опште-образовнх предмета (568) у односу на наставу вјештина (424). Посматрајући фреквенције укупне учесталости комуникација на групама предмета видимо да је на настави вјештина комуникација учесталија( 2734) у односу на општеобразовну групу предмета (2656).

Тестираћемо $\mathrm{X}^{2}$ тестом независности учесталост остварених комуникација према двије групе предмета: опште-образовних (српски језик, математика, природа и друштво) и вјештина (ликовна, музичка култура и физичко васпитање).

Прије него смо отпочели рачунање, поставили смо нулту и алтернативну хипотезу:

$\mathrm{X}_{0}$ - структура остварености, успјешности (остварена, успјешна/неостварена, неуспјешна) комуникација је независна од групе наставних предмета;

$\mathrm{X}_{1}$ - постоји значајно одступање у структури остварености комуникација у зависности од групе предмета.

Наредном табелом ћемо приказати теоријске вриједности комуникација по групама наставних предмета као и успјешности $(+)$ и неуспјешности (-) из којих ћемо извести вриједност $\mathrm{X}^{2}$ теста. 
Табела 8: Учесталост и оствареност комуникација према групама предмета (теоријске вриједности)

\begin{tabular}{llll}
\hline Остварена/неостварена & + & - & $\begin{array}{l}\text { Укупна } \\
\text { учесталост: }\end{array}$ \\
\hline Опште-образовна група & 2167,178 & 488,822 & 2656 \\
Вјештине & 2230,822 & 503,178 & 2734 \\
Укупно: & 4398 & 992 & 5390 \\
\hline
\end{tabular}

SPSS софтвер је дао следеће резултате: вриједност $\chi 2$ теста је $\mathbf{3 0 , 9 3 7}$ и тест је изведен уз 95\% прецизности.

Из таблице критичне вриједности $\chi 2$ распореда уз степен слободе $\mathrm{df}=(\mathrm{r}-1)(\mathrm{c}-1)=(2-1)(2-1)=1$, гдје $\mathrm{r}$ представља број редова, а с број колона посматране табеле контигенције, $\mathrm{X}_{0}^{2}$ je 3,841 . Пошто је добијена вриједнст $\mathrm{X}^{2}$ теста знатно већа од табличне критичне вриједности долазимо до закључка да се не може прихватити нулта хипотеза па је одбацујемо и закључујемо да постоји значајна разлика у структури остварености комуникација у зависности од групе наставних предмета.

Оволико велико одступање у вриједности $\mathrm{X}^{2}$ теста $\mathrm{y}$ оставрености комуникација према групама предмета је било и очекивано, јер је и сама припадност наставних предмета одређеној групи веома уочљива. Опште-образовна група предмета, односно настава српског језика, математике и природе и друштва је због ширине наставног плана и програма као и већег годишњег броја часова тих предмета, динамичнија, захтијева примјену различитих облика и метода рада и захтијева од ученика веће ангажовање током наставе. Наставни садржаји су занимљивији, обилују великим бројем нових информација, примјенљивих и у свакодневном животу и самим тим стављају ученика у активнији положај.

\section{ЗАКљУЧАК}

Комуникација у разредној настави је веома сложен процес и она од наставника захтијева широко опште образовање као и одлично познавање струке. У теоријском дијелу овог рада смо дефинисали појам педагошке комуникације под којим се подразумијава преношење, саопштавање, излагање, примање, тј. размјена порука као и успостављање односа, споразумијевање, средства и начин опхођења међу учесницима (факторима) у васпитно-образовном процесу и процесу учења. С обзиром на 
специфичности процеса комуникације, може се рећи да ефикасност педагошке комуникације у великој мејери зависи од умјешности наставника да ученика стави у позицију активног учесника васпитнообразовног процеса.

Познато је да је наша школа недовољно ефикасна, да још увијек није превазиђен традиционалан начин рада који се односи, између осталог, и на пасивну позицију ученика, неквалитетну и углавном једносмјерну комуникацију, резултати овог истраживања ће допринјети усавршавање и осавремењавање ефикасности педагошке комуникације код нас.

Истраживањем које је спроведено у мјесецу марту и априлу 2016. године у основним школама широм Републике Српске дало нам је јасне резултате за даље унапређење педагошке комуникације у разредној настави. Полазећи од постављених задатака истраживања дошли смо до бројних резултата који нам дају јасно тренутно стање у настави везано за подручје комуникације.

Анализом и интерпретацијом резултата долази се до закључка да је комуникација у разредној наставу углавном једносмјерна, одвија се у великом степену на релацији наставник-ученик, 45\% учесталости и остварености комуникација на овој релацији. Овим резултатом смо и потврдили прву постављену хипотезу којом смо тврдили да је комункација на релацији наставник-ученик најучесталија и најостваренија.

Што се тиче успјешности односно остварености комуникација према предметима на релацијама статистички значајна разлика постоји. Примјеном непараметријског Х2 теста смо утврдили значајност, гдје смо добили вриједност од 81,612 што нам доказује да постоји разлика у остварености комуникација у зависности од релације на којој се одвијала.

Такође смо упоредили вриједности неостварености, неуспјешнности комуникација на релацијама према предметима. Примјењујући исти тест уочили смо и статистичку разлику гдје је вриједност која је добијена била 34,6839 што је далеко изнад постављене граничне вриједности. Овим смо доказали да је постоји разлика и у неостварености комуникација у зависности од релација.

Другом хипотезом смо твдили да је комуникација учесталија и остваренија током наставе опште-образовних предмета (српског језика, математике и природе и друштва) тј. да постоји статистички значајна разлика у учесталости и остварености комуникација током 
наставе опште-образовних предмета. Утврдили смо да је фреквенција комуникација током наставе вјештина занемарљиво већа у односу на опште-образовну групу премдмета, али и такође да постоји статитстички значајна разлика у остварености и учесталости комуникација према групама предмета. Овим закључком смо другу хипотезу дјелимично потврдили.

Надамо се да ће ово истраживање донекле помоћи будућим истраживачима ове области, али и учитељима и наставницима који ове резултате могу да примјењују у пракси.

\section{ЛИТЕРАТУРА}

Брајша, П. (1994). Педагошка комуникологија. Загреб: Школске новине.

Вилотијевић, М. (2000). Предмет дидактике. Београд: Научна књига.

Граорац, И. (1995). Васпитање и комуникащија: Могућности освешћивања педагогије. Нови Сад: Матица српска.

Ивић, И. (1978). Човек као animal symbolicum: Развој симболичких способности. Београд: Нолит.

Measel, W., \& Mood, D.W. (1972). Teacher verbal behavior and teacher and pupil thinking in elementary school. The Journal of Educational Research, 66(3), 99-102.

doi:10.1080/00220671.1972.10884418

Мусић, Х., \& Муратовић, А. (2010). Комуникација у настави. Тузла: ОФФ-СЕТ.

Симеуновић, В., \& Спасојевић, П. (2005). Савремене дидактичке теме. Бијељина: Педагошки факултет.

Сузић, Н. (2005). Педагогија за ХХИ вијек. Бања Лука: ТТЦентар.

Flanders, N.A. (1984). Interaction Analysis in the Classroom: A Manual for Observers. Ann Arbor, MI: University of Michigan: School of Education.

Furst, N., \& Amidon, E. (1965). Teacher-pupil interaction patterns in the teaching of reading in the elementary school. The Reading Teacher, 18(4), 283-287. Retrieved from http://www.jstor.org/stable/20197913 
Шевкушић-Мандић, С. (1991). Облици вербалне комуникације између учитеља и ученика. Зборник Института за педагошка истраживања, 23, 232-260.

Шевкушић-Мандић, С. (1992). Стил понашања учитеља и социјално-емоционална клима у одељењу. Настава и васпитање, 41(3), 290-302.

\title{
PEDAGOGICAL COMMUNICATION - ACHIEVEMENT AND FREQUENCY IN GENERAL CLASS TEACHING
}

\author{
Danijela S. Panic ${ }^{2}$, Dragana D. Lazic ${ }^{1 *}$, Ljiljana Lj. Mitrovic ${ }^{3}$
}

Abstract: This paper deals with pedagogical communications, that is, the frequency and achievement of communication in general class teaching. The aim of this research is definition of frequency and achievement of pedagogical communication, regarding the communication direction (pupil-teacher, teacherpupil and pupil-pupil). Also, the aim of this research is to define the frequency and successfulness during teaching of subjects group (common - educational and skills) and to define the communication relation regarding to the type, that is, group which teaching subject belongs to. The nature of problem and set aim of research determined that this research has an empirical character. From the set aim and objective of this research, the following research tasks are derived: to establish the incidence and successfulness of pedagogical communication towards teaching subjects in general class teaching on relations teacher-pupil, pupilteacher, pupil-pupil, over 300 lessons; to establish whether there is statistically significant difference in communication achievement and underachievement towards teaching subjects on relations, in general class teaching; to establish whether there is statistically significant difference in the communication incidence and achievement between common educational group of teaching subjects and skills.

The research was conducted by method of observing, noting and specially designed instrument for this kind of data and research was used. The results shows that the communication is the most incident and most achieved on relation teacher - pupil, as well as that achievement and underachievement of communications depends on the type of teaching subject. Since the pedagogical

\footnotetext{
${ }^{2}$ simeunovic.danijela@gmail.com, ${ }^{1 *}$ draganaldj@gmail.com, Primary school „Knez Ivo od Semberije“, Bijeljina, Republic of Srpska, Bosnia and Herzegovina

3 mitroviclj@spinter.net, Primary school „Vuk Karadžić“, Zabrđe, Republic of Srpska, Bosnia and Herzegovina
} 
38

communication is very important part in pedagogical and educational work in our schools, this paper offers useful information for further studies, improvement of communication in teaching.

Key words: pedagogical communication, general class teaching, teaching subject, incidence, elementary school

Примљен: 13.05.2017.

Прихваћен: 04.07.2017.

(c) 